Logos Universality Mentality Education Novelty, Section: Social Sciences

ISSN: $2284-5747$ (print), ISSN: $2284-5747$ (electronic)

Covered in: CEEOL, Index Copernicus, Ideas RePEc, EconPapers, Socionet

\title{
EMIGRATION AND THE FUTURE OF YOUNG GENERATION IN BACĂU COUNTY, ROMANIA
}

\author{
Andreea MORARU
}

Logos Universality Mentality Education Novelty, Section:

Social Sciences, IV (1), 89-100

The online version of this article can be found at:

http://lumenjournals.com/social-sciences/

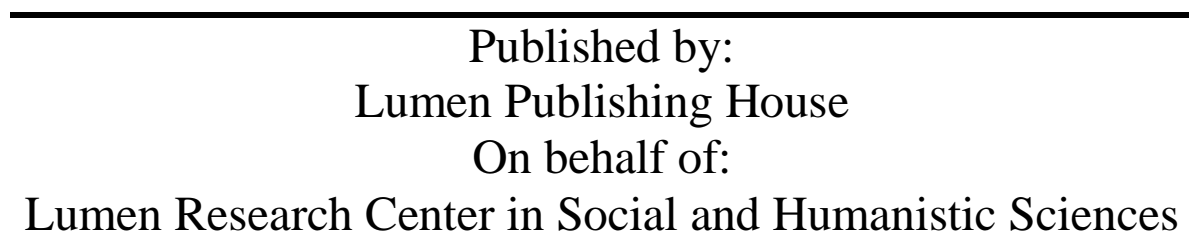




\title{
Emigration and the Future of Young Generation in Bacău County, Romania
}

\author{
Andreea MORARU ${ }^{1}$
}

\begin{abstract}
The approach of this article is to bring forward the long-term consequences of emigration over age population structure, visible in Bacău, which is a county from East Romania. Complexity of this social phenomenon provides us different perspectives of analyze and partial explanations concerning the present demographic situation that Bacău county is facing concerning emigration and its impact on age population structure, taking in count that this county register one of the strongest emigration in Romania.

Under economic, political and cultural pressure, people react by trying to find solutions for a better living, as emigration in this case, which has a long term negative impact. Even if it is often seen as an economic privilege, migration, and especially emigration in our case, cause major changes whose cyclical effects are manifested in demographic, social and economic aspects. Therefore, migration is the indirect result of political, economic and social conjecture with worrying implications on population. These implications, already visible in Bacău county, denounce a demographic decline redirected on changing the population age structure translated by a decrease of young population and an increase of old population rate. To reduce the syncope of a descriptive analysis, in this article are used collected data, from National Institute of Statistics, data that are outlined through cartographic method.
\end{abstract}

\section{Keywords:}

emigration, population, age structure, Bacău county, demographic impact.

1 PhD. Student, Alexandru Ioan Cuza University, Iaşi, Romania, moraru.andreea@yahoo.com. 


\section{Introduction}

Migration is often seen like a positive phenomenon, negative side of it being less mentioned. Among other consequences important to be mentioned is that, when expanded to all levels, there is a serious demographic impact on population structure. The purpose of this paper is to bring forward the loss of young population in Bacău County due to young people that choose to emigrate. Thereby, the dominant worrying feature of emigration consist in the dynamism of this process which decrease number of young population once because of the young people that choose to emigrate and second because of the decreasing of natality and the generation renewal capacity.

Migration temptation expanded and emigration of young people contribute to the destabilization of demographic factors of an area. This idea underlies the present study, which is intended as an analysis of a narrower territory, Bacău County, aware that no national analysis brings to the fore all the issues that become more visible with a research on a smaller area, the situation being often different. For interpretation of the specific data were used cartography and methods for transforming the data obtained from various public institutions, by using Excel and Philcarto. The study can be divided schematically into three steps: a preliminary documentation stage, research on the field, required to obtain relevant data, and a stage concentrated on analyzing, processing and mapping of information obtained.

\section{Literature review}

Studies on the demographic impact of migration had a late onset and slower growth while in the past was strongly supported the idea that only birth and death rates can influence the population. The best example of this is the modern mathematical demography founded by Alfred Lotka (1998/1939: 53), author who stated that "In a very natural abstraction, demographic analysis shows a starting point of a closed population, which means a population whose number changes only in terms of births and deaths, immigration and emigration being excluded.". Future studies come to precisely refute that idea, using concrete examples.

Fargues (2006) call emigrants "potential vectors for demographic change" arguing his affirmation by saying that emigrants have the power to change the demographic transition in the country of origin. Münz 
(2013) have the same opinion and he name emigrants "agents of change" in their home countries and regions. Because generally people emigrate from areas with high birth rates to those with low birth rate and since emigrants adopt and bring home the ideas, they are potential agents of diffusion of modern demography in the origin country. Migration is not therefore, as de Haas (2007) states, only a factor explaining the change, but also an integral part of the change itself. The ideas are the same, but they chose to highlight it in different ways.

Coleman (2008) stated that to analyze migration is very difficult while the data are scarce and the theory insufficient. A study on the impact of migration in origin country is really very difficult, especially in the case of Romania where official data show much lower number of emigrants than the unofficial data, differences being impressive. Comparing data concerning the emigrants registered in Romania with data of Romanian immigrants in host countries we will see the disparity. In this respect it was noted in Council of Europe (1993: 18) that it is difficult, almost illusory, to carry out a valid assessment of migration flows, taking in count only data registered in emission countries.

International migration, say Schoorl et al. (2000), is a selective process that occurs mostly among people aged between 20 and 29 years. Perhaps this is confirmed in his study on Morocco, but for Romania the situation is slightly different. According to the study conducted by Stănculescu et al (2011), most Romanian migrants leaving for the first time to work abroad are between 21 and 27 years. Then migration propensity decreases, in order to increase slightly at 35-37 years. After 44 years goes far fewer people, women to a greater extent than men.

Young people are more flexible on moving than older people, and through these preferences for young people, migration affects the age structure of Romania and even more importantly affect age groups with high rates of fertility, thus reducing the potential for birth rate in Romania, even more when emigration is permanent (Roman M., Voicu C., 2010).

Most Romanians who emigrate are young people who are part of the active age groups (Teodorescu, 1996; Andria, Souche, 2007), the age groups with high rates of fertility which automatically leads to dramatic changes in the distribution by age of population and the potential damage of newborns in Romania and of course the long term has a negative impact on young workforce. This is more worrying as it 
becomes permanent emigration for many young people who originally went with the idea of returning to their country.

The percentage of young people between 18-40 years in 2005 was $36 \%$ in the whole population of the country and the population emigrated after 1991 the same category represent 55\% of the population, according to the survey conducted in 2007 by Ghețău. The results of the 2011 census shows an unexpectedly large size of external migration. Given these data, we are able to state that the migration temptation expanded and emigration of young people contribute to the destabilization of demographic factors of a country.

\section{Results and discussions}

Negative migratory balance of Bacău is the most pronounced in the North-East Region of Romania, as it may be seen in Fig. 1. Neamt County also recorded a negative external migratory balance, characterized by a growing emigration. Thanks to immigrants, especially those from Republic of Moldova, Iaşi County is on the opposite with a positive migratory balance. Iaşi County situation is the most optimistic in this concern, especially Iaşi town, as, except the immigrants, there are also people coming from other counties, young population that remains, after coming to study, in the city of Iaşi and its surroundings. Iaşi seems the most attractive pole from the North-East Region while Bacău County is exactly the opposite. 


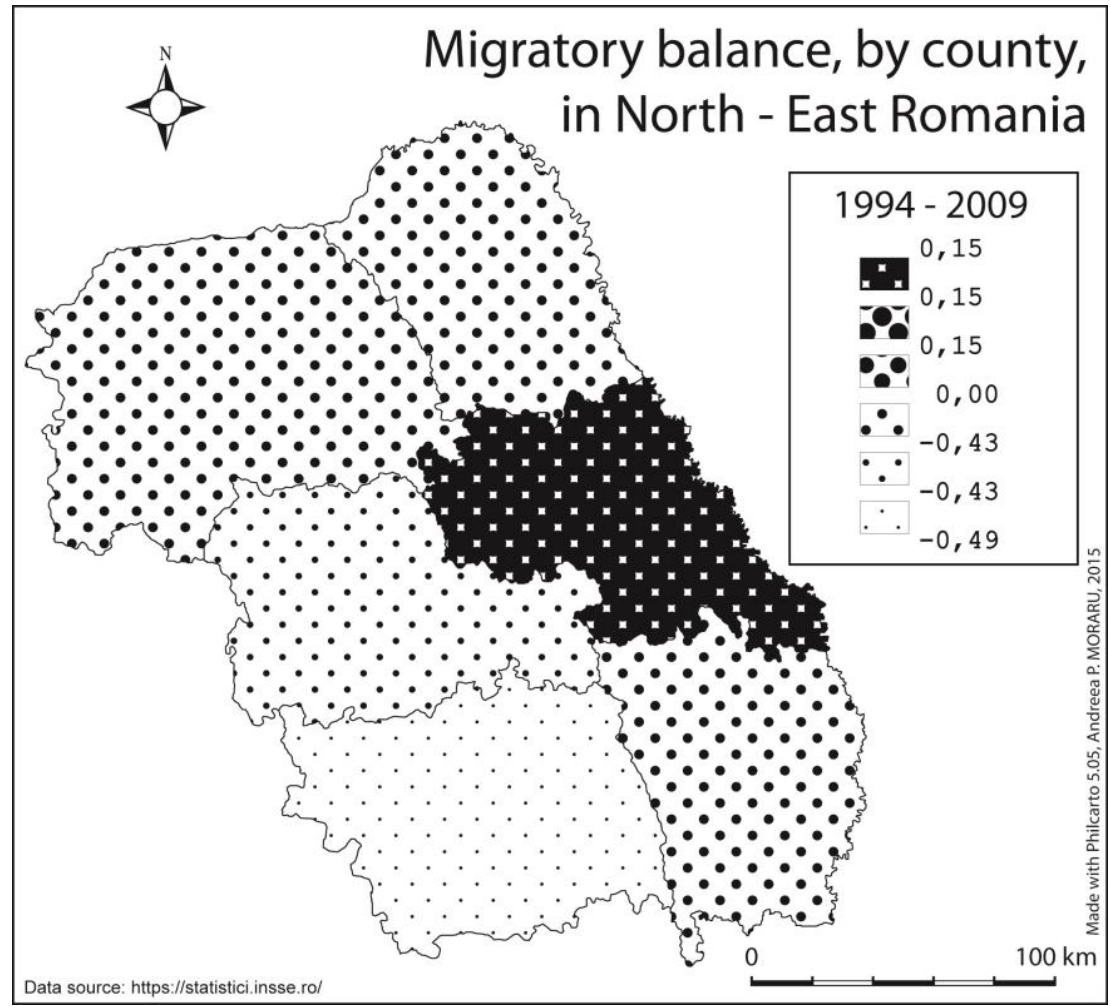

Fig. 1 Migratory balance, by county, in North-East Romania

Perhaps in the future this immigration will be seen as relief of an aging population, aging attributed to a negative natural growth and migration of youth to more developed countries. Emigration from Bacău county was, at the beginning, as many studies show, driven by religious bond, Catholicism having an important contribution to it.

The results of the 2011 census reveals, unfortunately, a large size of emigrant people from Bacău County, especially from central area. Given these data it can be noticed that the temptation of emigration expanded and the leave of young people contribute to the destabilization of demographic factors that a country depends of (Horvath, 2008). Major cities of this county register, as we see, the most intense population emigration. Bacău town is the most remarcable in this concern with more than 17000 emigrants registered at the last census. With less emigrants than Bacău, but not a number that could be neglected, there is Oneşti city followed closely by Buhuşi. As it was 
stated before, strong emigration from Bacău, produced early, due, among others, to Catholicism which has created strong links between individuals and communities, Catholics being the "pioneers of migration" in Romanian Moldova (Dimitriu et al., 2013: 103).

Repartition of emigration by areas reveals the important and visible differences between Eastern part of Bacău county in opposite with the Center and the Western part of it. In this concern mapping of statistical data is very useful as it allows us to see these differences. Administrative areas from the Eastern part register small number of emigrants proof that emigration manifests different from an area to another, factors that determinate it being so complex and sometime hard to be explained.

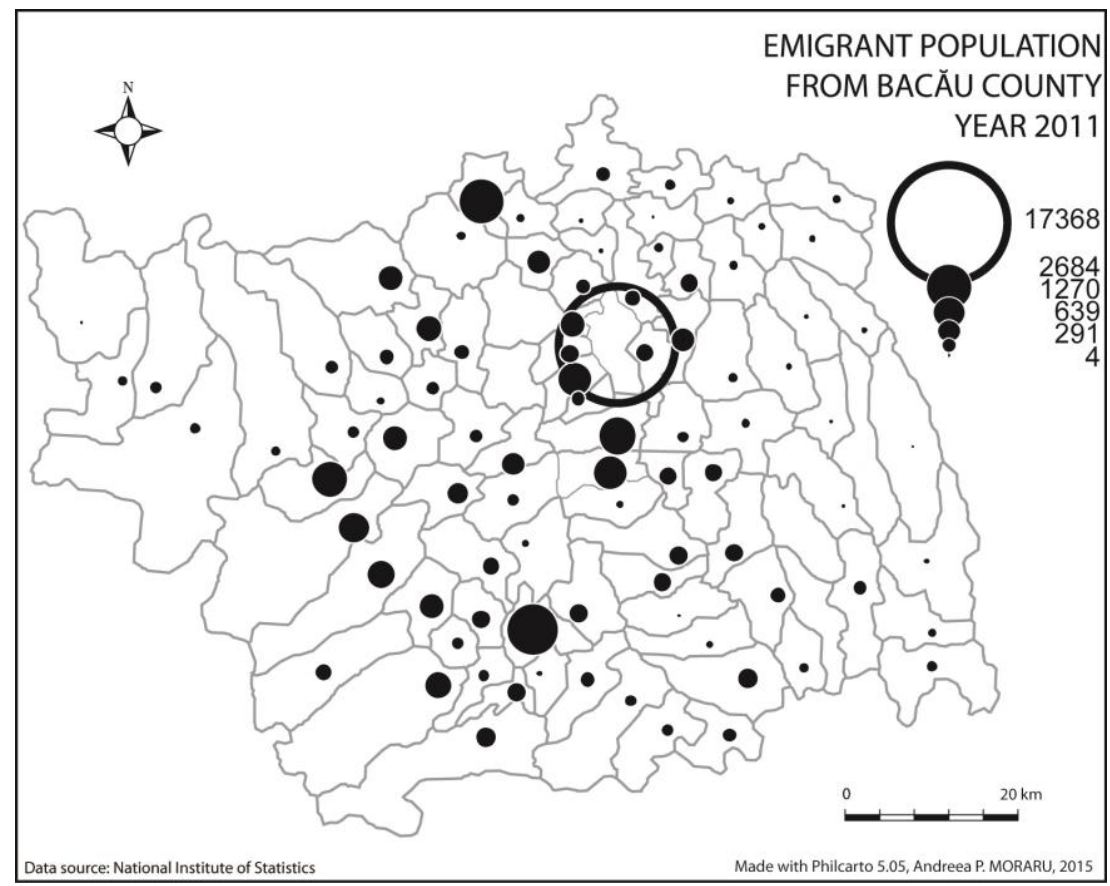

Fig. 2 Emigrant population from Bacău County, year 2011

Representation of percentages of emigration from total population per administrative area reveals a totally different situation from the one seen above when it was about effective numbers of emigrants. Rural areas loose through emigration the most significant 
percentage of inhabitants even if in effective numbers there are not so many emigrants comparing with cities like Bacău and Oneşti, cities mentioned before. Eloquent examples of rural areas that registered the most significant loses through emigration are: Luizi Călugăra, Faraoani and Nicolae Bălcescu, administrative areas that lost more than $20 \%$ of their population due to this phenomenon. Maybe the emigration from those rural areas mentioned above are the proof that emigration have been favoured by the fact that have predominant catholic inhabitants, creating links between emigrants facilitating, most of the times, emigration. In this way it becomes a lot easier to decide to emigrate when a person gets support from another emigrant, that already have experienced emigration knowing the risks he took when he decided to emigrate but also the benefits he had from emigration and he can even provide a job for the new emigrant.

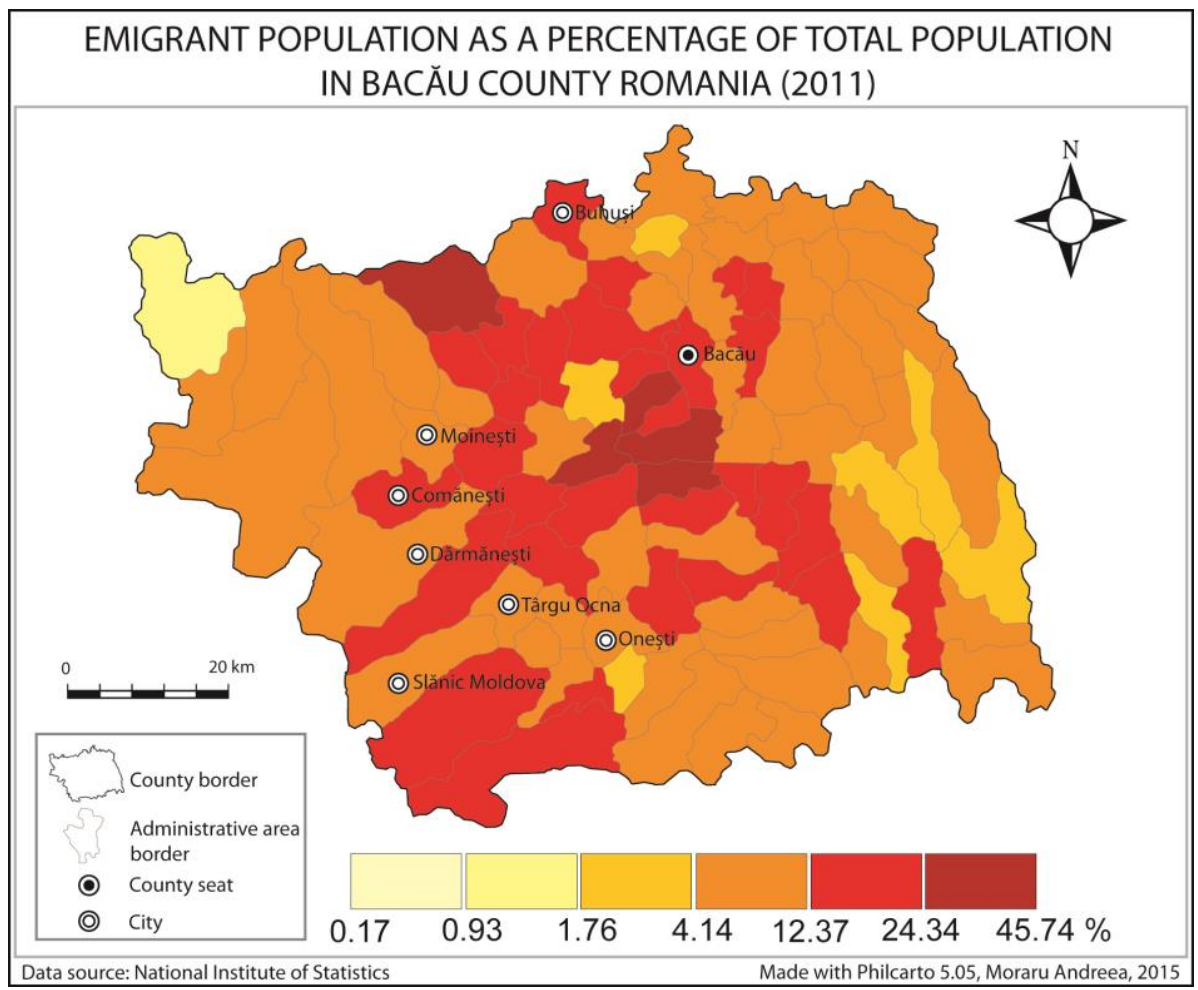

Fig. 3 Emigrant population as a percentage of total population in Bacău County, year 2011 
Even though Bacău town register the highest number of emigrants at the county level, when we calculate the percentage of emigrants from total inhabitants from this town, it results a less worrying situation, comparing with the rural areas mentioned above. Here we should mention also the positive impact of immigration and, even more important, the coming of people from other areas that chose to study and live in this town, thing that keep a high number of young people for Bacău Town. Strugari, Stănişești, Găiceana and Huruieşti register the lowest percentages of emigration with numbers bellow 0,47\%, Găiceana and Strugari having no emigrants registered at the census.

We might say that emigration is good as it reduce the numbers of unemployed people but, taking in count that the emigration is selective and emigrate mostly the young people, we should rethink the long term demographic impact over the situation of this County, and even country, if we think that this is a problem extended to a national level. In which concern Bacău County, because this is the area we analyze now, most of the emigrants are aged between 18 and 40 years, followed in most areas by the group 41-60 years, the population over 61 years having the smallest percentage, thing that we might have been supposed.

The rural area named Parincea stands out, and these not in a positive way, with a percentage of the $18-40$ age group below $70 \%$ from the total emigrants; that means almost all people that chose to emigrate are from this age group. In numbers that means 109 emigrants with ages between 18-40 from a total of 144 emigrants, while population number registered at the census was 3 805. The city of Bacau has the largest number of emigrant people in the age group 18-40, but a percentage of $55 \%$ from total emigrants; that means 9637 while the total absent persons registered in 2011 was 17368 .

Persons between 18-40 years are the most active in this concern, while the population aged 61 years and older is most of the times don 't even think to emigrate, possibility to find a job being smaller; usually they migrate in order to take care of their nephews, then when their children are emigrated and they don't have someone to take care of their children while they are at work. The long-term negative impact it might be presumed, future confronting with a pressure owe to increasing of elderly while numbers of young people decrease. The 
situation is even more dramatic in the isolated rural areas from the east of this town where old population is predominant, most of young people choosing to emigrate or simply to migrate to other areas from Romania where they hope for a better future and better opportunities for a hopeful future.

Structure by age, of the population in Bacău County, show an increasing in the number of elderly population while young population decrease due to a decreased natality and increased of emigration, but also internal migration. Being so, rural areas not only that lose population due to migration but even more important is that lose young people, which is materialised in a so called phenomenon of population aging.

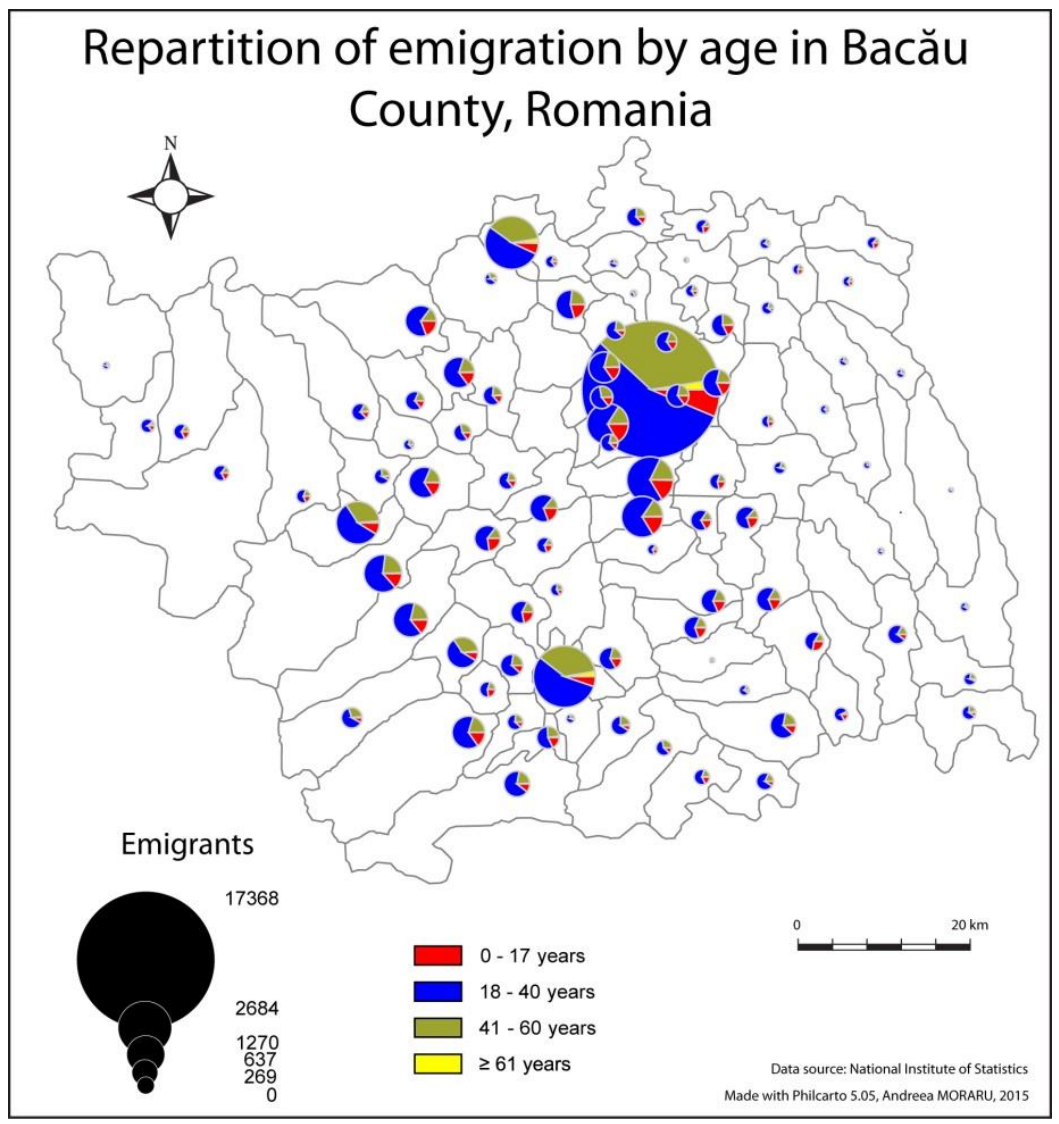

Fig. 4 Repartition of emigration by age in Bacău County, Romania 


\section{Conclusions}

This article takes in count emigration including emigration by age focusing on long-term demographic impact of emigration over age population structure, visible in Bacău County. Emigration affects age population structure while people that emigrate are mostly young, old people registering significantly less emigrants.

The spatial repartition of migratory balance between 1994 and 2009 reveals that negative migratory balance of Bacău is the most pronounced in the North East Region of Romania while Iaşi, on the oposite, benefit from a positive migratory balance, registering more immigrants than emigrants between the mentioned years.

Analysis concerning the repartition of effective number of emigrants in Bacău county show high numbers of emigrants from urban areas, especially Bacău town, while the analyse concerning the emigration percentages show that, during this period, rural areas lost more significant percentages of their inhabitants.

The map that give a visual image concerning repartition of emigration by age underline a more clear view over the reality faced by Bacău County`s administrative areas, taking in count that allows to see what category of age is more affected by emigration. As we have seen, most of the emigrants are between 18 and 40 years, followed in most areas by the age group 41-60 while the population over 61 years register the smallest percentages. All these realities have a long-term demographic impact over the population structure by age especially in the rural areas that already loose young population by internal migration.

\section{Acknowledgement:}

This work was published with the support of the ERASMUS MUNDUS Project EMERGE (Erasmus Mundus European Mobility with Neighbouring ReGion in the East), Action 2 - Strand 1 (20092013), Grant Agreement no. 2011-2576/001-001-EMA2, (Lot 8: Moldova, Ukraine, Belarus), funded by the European Union.

\section{References}

Andria L., Souche O., 2007, Le vieillissement démographique: quels enjeux pour les systèmes de protection sociale dans les Balkans 
(Grèce, Bulgarie, Roumanie et Albanie) à l'horizon 2051?, Rapport de Stage Master PODEPRO

Coleman, D., 2008, The demographic effects of international migration in Europe, Oxford Review of Economic Policy, Volume 24, Number 3, p 452-476

Council of Europe, 1993, Aspects politiques et demographique des flux migratoires vers l'Europe, Colection demographie, Etudes Demographiques no 25, Council of Europe Conseil de l'Europe, Strasbourg, France

de Haas, H., 2007, Migration, Remittances and Social Development. Geneva: United Nations Research Department for Social Development

Dimitriu, R., Muntele, I., Marcu, S., Dimitriu, A., 2013, Migratiile internationale ale populatiei din Moldova, Editura Universitatii „Alexandru Ioan Cuza”, Iasi

Fargues, P., 2006, The demographic benefits of international migration: a hypothesis and Its application to Middle Eastern and North African Countries, In C. Ozden \& M. Schiff (eds), International Migration, Economic Development and Policy, World Bank and Palgrave Macmillian, Washington DC

Ghetau, V., 2007, Declinul demografic si viitorul populatiei Romaniei. O perspectiva din anul 2007 asupra populatiei Romaniei în secolul 21, Academia Romana, Ed. Alpha MDN, Buzau

Horvath, I., 2008, The culture of migration of Rural Romanian Youth, Journal of Ethnic an Migration Studies, Volume 34, Number 5, Londra

Lotka, Alfred J., 1998 [1939], Analytical Theory of Biological Populations, New York and London: Plenum Press (English translation of [1934 \& 1939] Théorie analytique des associations biologiques, Paris: Hermann \& Cie)

Münz, R., 2013, Demography and migration: an outlook for the 21st century, Migration Policy Institute, Policy Brief, no.4, Washington, 1-13.

Roman, M., Voicu, C., 2010, Cateva efecte socioeconomice ale migratiei fortei de munca asupra tarilor de emigratie. Cazul Romaniei, Economie teoretica si aplicata, XVII(7): 50-65

Schoorl, J., Heering, L., Esveldt, I., Groenewold, G., van der Erf, R., 2000, Push and Pull Factors of International Migration: A 
Comparative Report, Luxembourg: Eurostat, European Communities, Office for Official Publications, Luxembourg

Stanculescu, M., Stoiciu, V., Alexe, I., Motoc, L., 2011, Impactul crizei economice asupra migratiei fortei de munca romanesti, Fundatiei Soros Romania, Friedrich-Ebert-Stiftung Bucuresti Teodorescu V., 1996, The Romania's Migration Movement and Population Distribution in the last 50 years, Manuscrit, Bucharest

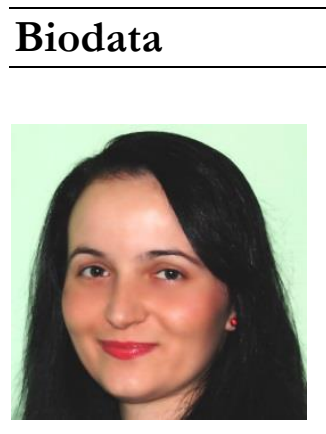

I have a bachelor's degree in Geography and master's degree in Tourism and Regional Development and I started doctoral school in 2012 at Faculty of Geography and Geology, Human Geography domain, having my research topic about geo-demographic impact of emigration.

My most recent publications/presentations are: Migrations - a socio-economic paradigm of our times comparative outlook: Bacău and Vaslui counties, Reduction of future generations. Emigration and birth rate in Bacău and Vaslui counties, Workforce Deruralization - A consequence of migration with implication over agriculture, Migration and religion in Romania: A study regarding the influence of migration behaviour on religion. 